\title{
Protective effect of Echinochrome against intrahepatic cholestasis induced by alpha-naphthylisothiocyanate in rats
}

\author{
Sohair R Fahmy ${ }^{a}$ (D), Dawlat A Sayed ${ }^{a}$ (D), Amel M Soliman ${ }^{a *}$ (D), Nesreen Y Almortada \\ Wafaa E Abd-El Aal

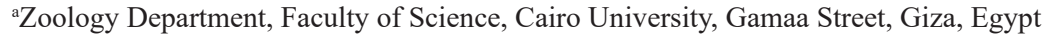 \\ 'Zoology Department, Faculty of Science, Sana'a University, El wahda street, Sana'a, Yemen \\ 'Pathology Department, National Research Center of Egypt, Tahrer Street, Dokki, Giza, Egypt \\ *e-mail: soliman.ame15@gmail.com
}

Received: March 9, 2018 - Accepted: November 10, 2018 - Distributed: February 28, 2020

(With 3 figures)

\begin{abstract}
The present study was designed to evaluate the protective effects of echinochrome (Ech) on intrahepatic cholestasis in rats induced by a single (i.p.) injection of alpha-naphthylisothiocyanate (ANIT) $(75 \mathrm{mg} / \mathrm{kg}$ body weight). The rats were pre-treated orally for $48 \mathrm{hr}$ (one dose / $24 \mathrm{hr}$ ) with Ech $(1,5 \mathrm{and} 10 \mathrm{mg} / \mathrm{kg}$ body weight) or ursodeoxycholic acid (UDCA) $80 \mathrm{mg} / \mathrm{kg}$ body weight drug then, injected with ANIT. ANIT markedly increased serum activities of alanine amino transaminase (ALT), aspartate amino transaminase (AST) and alkaline phosphatase (ALP), which was accompanied by a massive inflammation of epithelial cells on bile duct at $24 \mathrm{~h}$ after ANIT injection. ANIT also increased the levels of total protein (TP), total bilirubin (TB), direct bilirubin (DB), indirect bilirubin (IB), however decrease albumin content (ALB). In addition ANIT increased hepatic MDA and NO level and decreased GSH level and GST activity. The Ech exerted hepatoprotective and anticholestatic effects as assessed by a significant decrease in the activities of serum AST, ALT and ALP, and the levels of TP, TB, DB and IB as well as liver MDA level and NO level. In conclusion, Ech was found to possess hepatoprotective effect against intrahepatic cholestasis induced by hepatotoxin such as ANIT.
\end{abstract}

Keywords: cholestasis, Alpha naphthylisothiocyanate, echinochrome, Ursodeoxycholic acid, oxidative stress.

\section{Efeito protetor de Echinochrome contra colestase intra-hepática induzida por isotiocianato de alfa-naftilo em ratos}

\begin{abstract}
Resumo
O presente estudo destinou-se a avaliar os efeitos protetores do Ech na colestase intra-hepática em ratos induzidos por uma única injeção (i.p.) de alfa-naftilisotiocianato (ANIT) $(75 \mathrm{mg} / \mathrm{kg}$ de peso corporal). Os ratos foram pré-tratados oralmente durante 48 horas (uma dose / 24 horas) com cada (1,5 e $10 \mathrm{mg} / \mathrm{kg}$ de peso corporal) e ácido ursodeoxicólico (UDCA) $80 \mathrm{mg} / \mathrm{kg}$ de peso corporal, em seguida, injetado com ANIT. ANIT atividades de soro marcadamente aumentadas de alanina amino transaminasa (ALT), aspartato de amino transaminases (AST) e fosfatase alcalina (ALP), que foi acompanhada por uma inflamação maciça de células epiteliais no ducto biliar às $24 \mathrm{~h}$ após a injeção de ANIT. A ANIT também aumentou os níveis de proteína total (TP), bilirrubina total (TB), bilirrubina direta (DB), bilirrubina indireta (IB), no entanto, diminuem o teor de albumina (ALB). Além disso, a ANIT aumentou o nível de MDA hepático e NO e diminuiu o nível de GSH e a atividade de GST. O Ech exerceu efeitos hepatoprotectores e anticolestáticos como avaliado por uma diminuição significativa nas atividades de AST sérica, ALT e ALP e os níveis de TP, TB, DB e IB, bem como o nível de MDA no fígado e o nível de NO. Ech foi encontrado para possuir efeito protetor no fígado contra a colestase intra-hepática induzida por hepatotoxina, como a ANIT.
\end{abstract}

Palavras-chave: Colestase, isotiocianato de alfa naftilo, equinocromo, ácido ursodesoxicólico, estresse oxidativo.

\section{Introduction}

The liver is the most important metabolic organ that plays a major role in the metabolism, detoxification, storage and secretory functions in the body (Swarnalatha and Reddy, 2012). Ultimately the liver damage causes biliary fibrosis and cirrhosis and the end-stage of liver disease requiring liver transplantation (El-Sisi et al., 2013). Cholestasis is a reduction in bile flow that leads to the intrahepatic accumulation of bile acids and other toxic compounds with progression of liver pathology, including hepatocellular injury and fibrosis (Chen et al., 
2016). Generally, cholestasis is classified as extrahepatic and intrahepatic (Jüngst et al., 2013).

Intrahepatic cholestasis was shown to develop during treatment by different medical drugs as a toxic side effect (Krell et al., 1982). The most common experimental models of intrahepatic cholestasis are estrogen-induced, endotoxin-induced and drug-induced cholestasis (Rodriguez-Garay, 2003). Alpha-naphthylisothiocyanate (ANIT) is a widely used chemical to induce intrahepatic cholestasis in experimental animals (Xu et al., 2004). In experimental medicine, ANIT has been widely used to describe cholestatic alterations and its compensatory mechanisms (Korolenko et al., 2012).

Oxidative stress has been implicated in the process of liver fibrogenesis (Liu et al., 2013). Cholestatic liver fibrosis is associated with bile acid-induced oxidative stress and lipid peroxidation (Han et al., 2012). Furthermore, oxidative stress aggravates liver fibrosis via stellate cell activation (SvegliatiBaroni et al., 1998). Moreover, the bile salts are partly responsible for the plasma membrane damage which leads to further oxidative stress (Sokolovic et al., 2013).

Marine natural products provide a rich source of chemical diversity that contribute to the design and development of new and useful therapeutic drugs (Datta et al., 2015). Echinoderms have already been reported to contain pharmacologically active compounds with respect to antihistaminic, cytotoxicity (Riguera, 1997) and antiangiogenicity (Pandit et al., 2009). Sea urchins or urchins are small, spiky, spherical echinoderm animals (Ho et al., 2014). Echinochrome (Ech), or 7 (2) -ethyl-2, 3, 5, 6, 8-pentahydroxy-1, 4-naphthoquinone, is one of several spinochromes that occur as pigments in the shells and gonads of sea urchins (Lennikov et al., 2014). It was reported that, the use of sea urchin shells confers certain beneficial advantages, including antioxidant and pharmaceutical effects (Leng et al., 2014).

Thereby, this work will design to assess the protective effect of sea urchin Paracentrotus lividus, echinochrome (Ech) pigments on acute intrahepatic cholestasis induced by ANIT in rats.

\section{Materials and Methods}

\subsection{Chemicals and reagents}

Alpha-naphthylisothiocyanate (ANIT) was purchased from Sigma-Aldrich (St. Louis, MO, USA). Ursofalk (ursodeoxycholic acid) (UDCA) was obtained from MINAPHARM, under license by, Dr Falk Pharma, Germany). Kits for all biochemical parameters serum, and Tris-HCl buffer (pH 7.4) were purchased from Biodiagnostic Company (El Moror St, Dokki, Egypt). All these chemicals and reagents were of good quality and freshly prepared in vehicles just before use.

\subsection{Sea urchins collection}

Fifty of Sea urchins (Paracentrotus lividus) were collected from the Mediterranean coast of Alexandria (Egypt). The samples were thoroughly washed with sea water to remove sand and transported to the laboratory packed in ice. The collected specimens were immediately shade dried, and identified according to taxonomic guide (Clark and Rowe, 1971).

\subsection{Echinochrome (Ech) Extraction}

Echinochrome (Ech) pigments in the gonads, shells and spines of 50 Paracentrotus lividus were isolated by the Amarowicz method with some modifications (Kuwahara et al., 2009). Shells, spines and gonads were washed with a stream of cold water, air-dried at $4{ }^{\circ} \mathrm{C}$ for 2 days in the dark. The dried samples were grounded and the powders $(5 \mathrm{~g})$ were dissolved in $10 \mathrm{ml}$ of $6 \mathrm{M} \mathrm{HCl}$. The pigments in the solution were extracted 3 times with the same volume of diethyl ether. The collected ether layer was washed with $5 \% \mathrm{NaCl}$ until the acid was almost removed. The pigments suspended in the ether solution were dried over anhydrous sodium sulfate and the solvent was evaporated using rotary evaporator apparatus. The total quantity of pigments $(320.987 \mathrm{mg})$ was stored at $-30{ }^{\circ} \mathrm{C}$ in the dark.

\subsection{Experimental animals}

Male Wistar rats (Rattus norvegicus) weighing 150-160 g were used in the study. The animals were obtained from the National Research Center (NRC, Dokki, Giza). Animals were maintained in the well-ventilated animal house of the Zoology Department, Faculty of Science, Cairo University in a friendly environment with a $12 \mathrm{hrs}$. $/ 12 \mathrm{hrs}$. light-dark cycle at room temperature $\left(22{ }^{\circ} \mathrm{C}-25^{\circ} \mathrm{C}\right)$. Animals were grouped and housed in polyacrylic cages (six animals/cage) and given food and water ad libitum. Rats were acclimatized to laboratory conditions for 7 days before the commencement of the experiment.

\subsection{Experimental design}

Thirty six male Wistar rats were assigned into two main groups. Control group (6 rats/ group) and ANIT group (30 rats/ group). The animals of group 1 received DMSO 5\% solution orally daily for $72 \mathrm{~h}$. The second group was divided into 5 subgroups ( 6 rats/ subgroup). Rats of these subgroups orally treated daily for $48 \mathrm{~h}$ with DMSO $5 \%$ solution (subgroup 1); Ech (dissolved in DMSO 5\% solution) at dosages of 1,5 and $10 \mathrm{mg} / \mathrm{kg}$ body weight (Lennikov et al., 2014) (subgroups 2, 3\& 4, respectively) and UDCA (dissolved in DMSO 5\% solution), $80 \mathrm{mg} / \mathrm{kg}$ body weight (subgroup5). After $24 \mathrm{hrs}$. of the last dose, the rats of these subgroups will be fasted for $15 \mathrm{hrs}$. and received a single intraperitoneal (i.p.) injection of ANIT (dissolved in olive oil), at a dosage of $75 \mathrm{mg} / \mathrm{kg}$ body weight to induce the intrahepatic cholestasis as described previously by Ohta et al. (2006).

\subsection{Animals handling}

After 24h of ANIT injection, rats were euthanized under deep anesthesia with an i.p injection of sodium pentobarbital (dissolved in distilled water) $(40 \mathrm{mg} / \mathrm{kg}$ body weight). Blood was collected by cardiac puncture and then centrifuged at $3000 \mathrm{rpm}$ for $10 \mathrm{~min}$. Liver was carefully removed and immediately blotted using filter 
paper to remove traces of blood and then divided into two parts, the first part stored at $-80{ }^{\circ} \mathrm{C}$ for biochemical analysis. While, the second part was suspended in $10 \%$ formaldehyde solution for fixation and preparation to histological processing.

\subsection{Samples preparation}

Blood samples collected in centrifuge tubes were centrifuged at $3000 \mathrm{rpm}$ for 10 minutes. Serum stored at $-20{ }^{\circ} \mathrm{C}$ until used for biochemical assays.

Liver tissues were homogenized (10\% w/v) using Potter Elvehjem Homogenizer in ice-cold $0.1 \mathrm{M}$ Tris-HCl buffer ( $\mathrm{pH}$ 7.4). The homogenate was centrifuged at $3000 \mathrm{rpm}$ for $15 \mathrm{~min}$. at $4{ }^{\circ} \mathrm{C}$ and the resultant supernatant was used for biochemical analysis.

\subsection{Biochemical analysis}

\subsubsection{Liver function tests}

The appropriate kits (Bio-Diagnostic, Dokki, Giza, Egypt) was used for the determination of serum aminotransferase enzyme activities (AST and ALT) according to the calorimetric method described by Reitman and Frankel (1957), total protein (TP) levels (Tietz, 1994), and serum albumin (ALB) (Tietz, 1990).

\subsubsection{Serum cholestatic indices}

The alkaline phosphatase (ALP) activity and levels of total bilirubin, (TB) and direct bilirubin (DB) and indirect bilirubin (IB) were determined by colorimetric method using Biodiagnostic kit, according to Belfield and Goldberg (1971) and Levinsky et al. (1970), respectively.

\subsubsection{Oxidative stress parameters}

MDA level is an index of lipid peroxidation and it was estimated by Ohkawa et al. (1979), glutathione reduced (GSH) (Beutler et al., 1963), glutathione-S-transferase (GST) (Habig et al., 1974), and nitric oxide (NO) (Montgomery and Dymock, 1961) were determined in the liver homogenate supernatant using Biodiagnostic kits (Giza, Egypt).

\subsection{Histological methods}

\subsubsection{Hematoxylin and eosin}

Liver slices were fixed in $10 \%$ buffered formaldehyde solution. A routine method of dehydration in ascending series of ethanol, clearing with xylene and embedding in paraffin wax to form blocks was used. Sections of
$5 \mu \mathrm{m}$ thickness were sliced using microtome and were stained with Hematoxylin and Eosin stain (Bancroft and Gamble, 2007).

\subsubsection{Morphometrical methods}

The morphometric analysis was performed at the Pathology Department, National Research Center using the Leica Qwin 500 Image Analyzer (LEICA Imaging Systems Ltd, Cambridge, England,) which consists of Leica DM-LB microscope with JVC color video camera attached to a computer system Leica Q 500IW. We placed the slide to be examined on the stage of the microscope, and focus it at power magnification $(200 \mathrm{X})$. The light source is set to the required level. Successful adjustment of illumination is checked for on the video monitor (Baak and Oort, 1983).

The morphometric analysis was carried out on haematoxylin and eosin stained slides to measure the portal area in the studied cases on a real- time image from the microscope that we visualize on the video monitor. The portal area to be measured is covered automatically by a green mask which is called binary image. Areas $\left(\mu \mathrm{m}^{2}\right)$ of portal tracts were measured in five randomly fields per group and the data obtained as mean area and standard error.

\subsection{Statistical analysis}

Values were expressed as means $\pm \mathrm{SE}$. To evaluate differences between the control and treatment groups, one way analysis of variance (ANOVA) with Duncan's post hoc test was used to compare the group means and $P<0.05$ was considered to show the statistically significant for all comparisons. Using SPSS for Windows (version 20.0) was used for the statistical analysis.

\section{Results}

\subsection{Serum biomarkers for liver functions}

Alpha-naphthylisothiocyanate (ANIT) group showed a significant $(\mathrm{p}<0.05)$, increase in the serum activities of AST, ALT and total protein (TP) level and a decrease in serum albumin (ALB) as compared to the corresponding control group (Table 1). However, the administration of Ech at dosages of 5 and $10 \mathrm{mg} / \mathrm{kg}$ body weight and UDCA significantly decreased $(\mathrm{p}<0.05)$ AST, ALT, TP levels and increased serum ALB content. While, the administration

Table 1. Effect of Echinochrome (Ech) on serum enzymes biomarkers for liver function, total protein and albumin levels in serum of cholestatic rats induced by alpha-naphthylisothiocyanate (ANIT).

\begin{tabular}{ccccc}
\hline $\begin{array}{c}\text { Experimental } \\
\text { Groups }\end{array}$ & AST (IU/L) & ALT (IU/L) & TP (mg/100 ml) & ALB (g/100 ml) \\
\hline Control & $26.44 \pm 2.47^{\mathrm{a}}$ & $46.26 \pm 5.78^{\mathrm{bc}}$ & $8.31 \pm 0.23^{\mathrm{a}}$ & $2.97 \pm 0.11^{\mathrm{c}}$ \\
ANIT & $77.41 \pm 5.95^{\mathrm{c}}$ & $76.42 \pm 1.96^{\mathrm{d}}$ & $13.05 \pm 0.34^{\mathrm{d}}$ & $1.85 \pm 010^{\mathrm{a}}$ \\
Ech. (1mg) & $41.2 \pm 4.07^{\mathrm{ab}}$ & $60.35 \pm 3.94^{\mathrm{cd}}$ & $11.07 \pm 0.26^{\mathrm{bc}}$ & $2.34 \pm 0.06^{\mathrm{b}}$ \\
Ech. (5mg) & $39.34 \pm 6.26^{\mathrm{ab}}$ & $38.94 \pm 4.86^{\mathrm{ab}}$ & $10.12 \pm 0.31^{\mathrm{b}}$ & $2.88 \pm 0.14^{\mathrm{c}}$ \\
Ech. (10mg) & $32.91 \pm 5.49^{\mathrm{a}}$ & $25.94 \pm 9.57^{\mathrm{a}}$ & $9.86 \pm 0.65^{\mathrm{b}}$ & $2.95 \pm 0.18^{\mathrm{c}}$ \\
UDCA (80mg) & $53.22 \pm 3.74^{\mathrm{b}}$ & $56.04 \pm 8.94^{\mathrm{bc}}$ & $11.78 \pm 0.47^{\mathrm{c}}$ & $2.95 \pm 0.11^{\mathrm{c}}$ \\
\hline
\end{tabular}

Data are means \pm SEM of six rats in each group. Unshared letters between groups are the significance values at $\mathrm{p}<0.05$. 
of Ech ( $1 \mathrm{mg} / \mathrm{kg}$ body weight) non significantly decreased $(\mathrm{p}>0.05)$ ALT level.

\subsection{Serum cholestatic indices}

Results recorded in table 2 showed that serum ALP activity is significantly $(\mathrm{P}<0.05)$ increased after administration of ANIT at a dosages of $75 \mathrm{mg} / \mathrm{kg}$ body weight as compared to the corresponding control group. Moreover, total bilirubin (TB), direct bilirubin (DB), and indirect bilirubin (IB) levels significantly increased $(\mathrm{P}<0.05)$ in ANIT group as compared to control. In Ech pretreatment groups, serum ALP activity, TB, DB and IB levels were significantly decreased $(\mathrm{P}<0.05)$ as compared to ANIT group. Also, the administration of UDCA ( $80 \mathrm{mg} / \mathrm{kg}$ body weight) caused a significant decrease $(\mathrm{P}<0.05)$ in serum ALP activity, $\mathrm{TB}$, and IB as compared to ANIT group.

\subsection{Assessment of oxidative stress markers in liver}

In figure 1, hepatic malondialdehyde (MDA) and NO activities were found to be significantly increased $(\mathrm{P}<0.05)$ in the ANIT group as compared to control group. The pretreatment with all different Ech dosages of 1,5 and $10 \mathrm{mg} / \mathrm{kg}$ body weight and UDCA $80 \mathrm{mg} / \mathrm{kg}$ body weight significantly decreased $(\mathrm{P}<0.05)$ MDA levels and NO activities as compared to ANIT group. The higher decrease in MDA levels and NO were recorded with subgroup Ech (10 mg/kg body weight). (Figure 1a and 1d). In addition, the hepatic glutathione reduced (GSH) content

Table 2. Effect of Echinochrome extract on serum cholestatic markers of cholestatic rats induced by ANIT.

\begin{tabular}{ccccc}
\hline $\begin{array}{c}\text { Experimental } \\
\text { Groups }\end{array}$ & ALP $(\mathbf{I U} / \mathbf{L})$ & TB $(\mathbf{m g} / \mathbf{d l})$ & DB $(\mathbf{m g} / \mathbf{d l})$ & IB (mg/ dl) \\
\hline Control & $111.08 \pm 8.01^{\mathrm{a}}$ & $2.21 \pm 0.08^{\mathrm{a}}$ & $0.83 \pm 0.12^{\mathrm{a}}$ & $1.38 \pm 0.08^{\mathrm{a}}$ \\
ANIT & $183.76 \pm 5.85^{\mathrm{c}}$ & $8.13 \pm 0.66^{\mathrm{d}}$ & $3.77 \pm 1.03^{\mathrm{c}}$ & $4.36 \pm 0.63^{\mathrm{b}}$ \\
Ech. (1mg) & $145.04 \pm 6.34^{\mathrm{b}}$ & $3.67 \pm 0.3^{\mathrm{bc}}$ & $2.28 \pm 0.19^{\mathrm{b}}$ & $1.38 \pm 0.38^{\mathrm{a}}$ \\
Ech. (5mg) & $118.12 \pm 5.45^{\mathrm{a}}$ & $2.85 \pm 0.15^{\mathrm{ab}}$ & $2.18 \pm 0.11^{\mathrm{ab}}$ & $0.67 \pm 0.16^{\mathrm{a}}$ \\
Ech. (10mg) & $112.46 \pm 2.67^{\mathrm{a}}$ & $2.7 \pm 0.08^{\mathrm{ab}}$ & $2.04 \pm 0.08^{\mathrm{ab}}$ & $0.65 \pm 0.04^{\mathrm{a}}$ \\
UDCA (80mg) & $149.68 \pm 6.52^{\mathrm{b}}$ & $3.95 \pm 0.37^{\mathrm{c}}$ & $2.47 \pm 0.33^{\mathrm{bc}}$ & $1.48 \pm 0.12^{\mathrm{a}}$ \\
\hline
\end{tabular}

Data are means \pm SEM of six rats in each group. Unshared letters between groups are the significance values at $\mathrm{p}<0.05$.
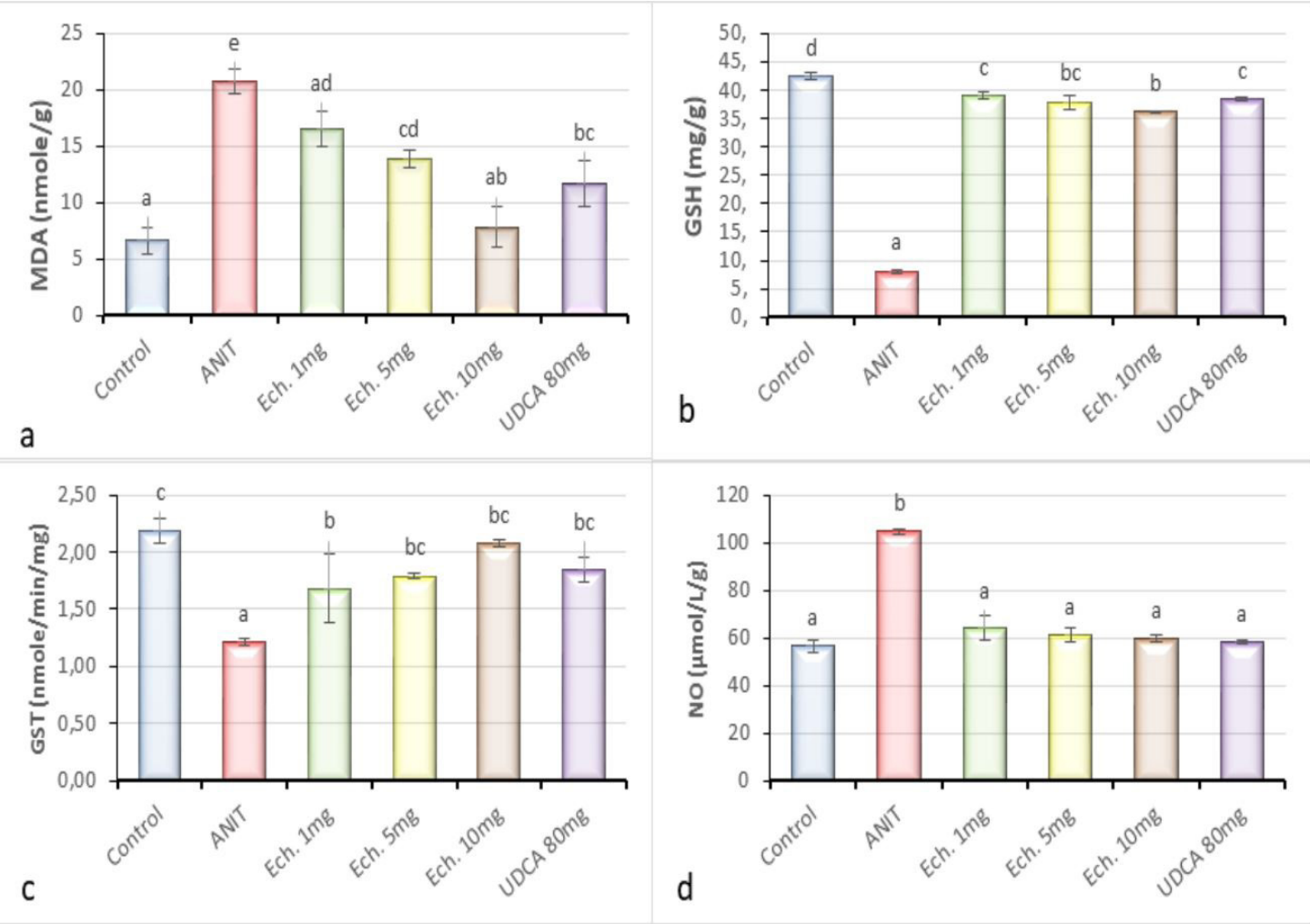

Figure 1. The protective potency of echinochrome (Ech) on some hepatic oxidative stress parameters and nitric oxide activity of choleststic rats induced by ANIT, Values are means \pm SE ( $n=6$ per group). Each value not sharing a common letter superscript is significantly different $(\mathrm{p}<0.05)$. 
and the activity of glutathione-S-transferase (GST) showed marked significant $(\mathrm{P}<0.05)$ decrease in the ANIT group compared to control group. Administration of 5 and $10 \mathrm{mg}$ of Ech and UDCA significantly $(\mathrm{P}<0.05)$ increased the levels of GSH and GST activities as compared to ANIT group. While, the administration of Ech at a dosage of $1 \mathrm{mg} / \mathrm{kg}$ body weight significantly $(\mathrm{p}<0.05)$ increased in the GST activity, but non significantly $(\mathrm{p}>0.05)$ increased GSH content (Figure 1b and 1c).

\subsection{Histological examinations}

Histological evaluation provided evidence of the protective effect of Ech on liver against ANIT-induced cholestasis (Figure 2). The the H \& E staining liver sections exhibited normal morphological structure in control rats (Figure 2AI) and morphometric analysis showed small area of portal tract (Figure 2AII). The liver specimens of ANIT-induced cholestasis rats revealed degenerative changes of the bile duct (Figure 2BI) and morphometric analysis showed an enlarged area of portal tract (Figure 2BII). In contrast, pretreatment with Ech at the different three doses protect the liver tissues from ANIT dependent damage (Figures 2CI, DI and EI) and morphometric analysis showed normal area of portal tract (Figures 2CII, DII and EII).

Figure 3 showed that the portal tract area of ANIT group rats was significantly increased $(\mathrm{p}<0.05)$ as compared to that of the control ones. However, the portal tract area of all treatment groups was significantly decreased as compared to that of the ANIT group (Figure 3).

\section{Discussion}

Liver disease is a major serious public health problem due to its high prevalence worldwide (Wang et al., 2014). Cholestasis is a clinical disorder defined as an impairment of bile flow, and that leads to toxic bile acid accumulation in hepatocytes (Yan et al., 2017). Experimental models of cholestasis in laboratory animals allow us to evaluate the pathophysiological and molecular mechanisms of this

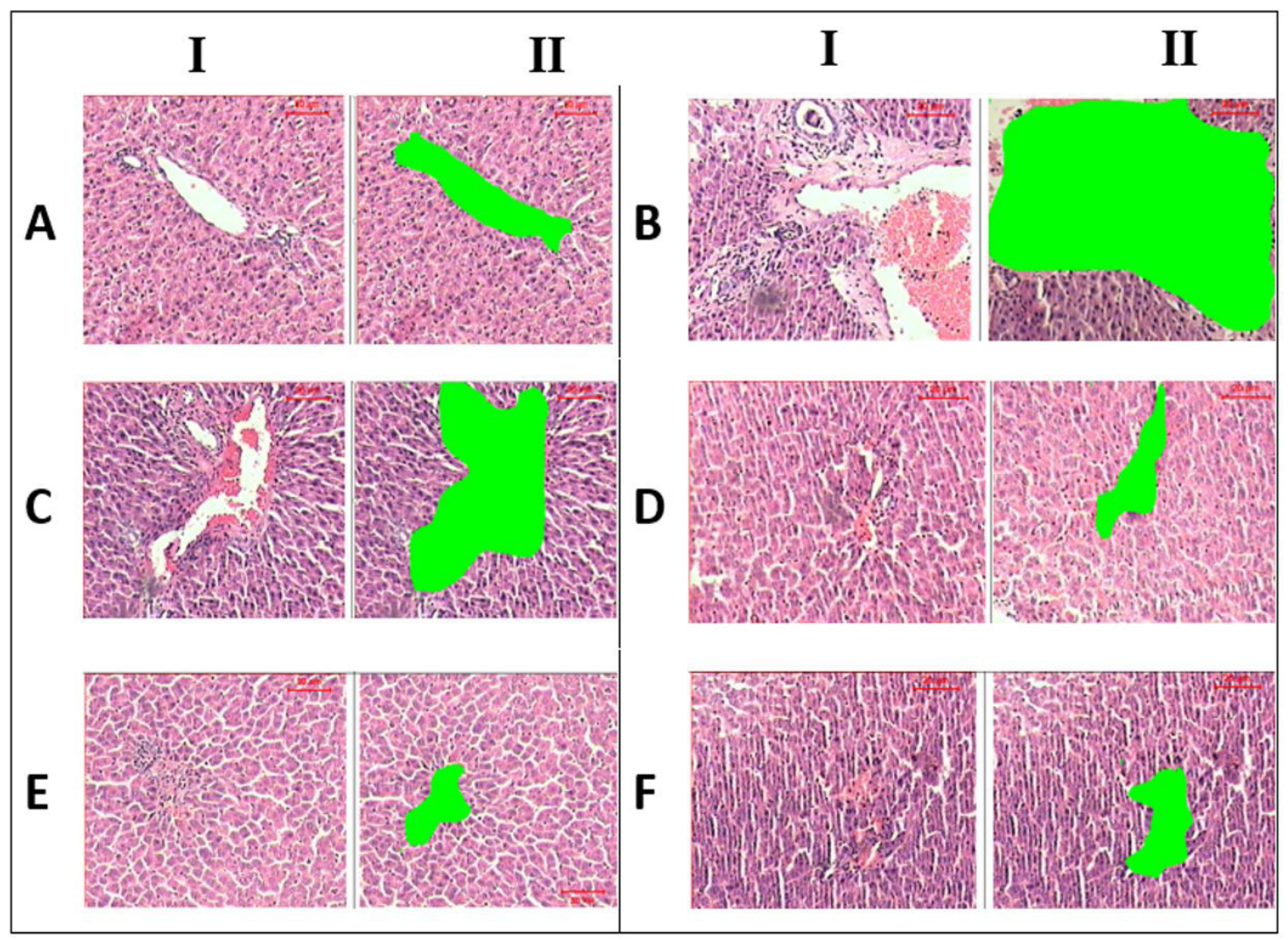

Figure 2. liver sections of (A): Control group showing normal portal triad composed of bile duct hepatic artery and portal vein. (B): Rat treated with ANIT after 24 hours showing widening of the portal tract (BII), hemorrhage and edema, proliferation of bile ducts surrounded by inflammatory cell infiltration (BI). (C), (D) and (E): Three subgroups of rats treated for 48 hours with different doses of Ech followed by ANIT injection; (C) Ech $1 \mathrm{mg} / \mathrm{kg}$ medium sized area of portal tract with dilatation of portal vein with some inflammatory cells, (D) Ech $5 \mathrm{mg} / \mathrm{kg}$ showing small portal tract area with some inflammatory cells, (E) Ech $10 \mathrm{mg} / \mathrm{kg}$ there is a prominent decrease in the portal tract area (nearly the normal size) with few inflammatory cells. (F): Subgroup of rat that treated with UDCA $80 \mathrm{mg} / \mathrm{kg}$ showing small portal tract area with some inflammatory cells. I. Haematoxlin and eosin photos of the sections. II. Binary image covered by a green mask. H\&E X 200. 


\section{Area of portal tracts $\left(\mu \mathrm{m}^{2}\right)$}

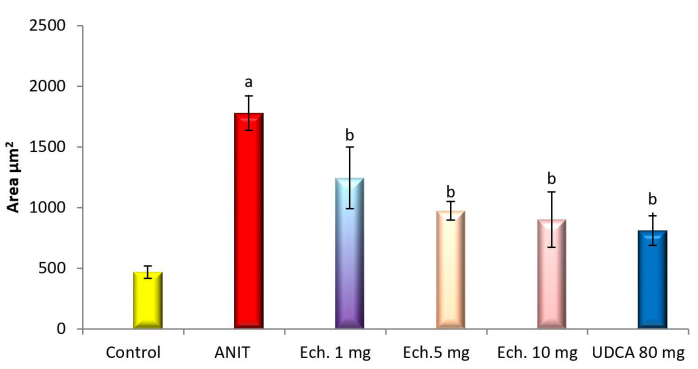

Figure 3. Mean areas $\left(\mu \mathrm{m}^{2}\right)$ of portal tracts were measured in six randomly fields per group in rats. ${ }^{\text {a: }}$ Significant increase at $P<0.05$ as compared with control group. ${ }^{\text {b: }}$ Significant decrease at $P<0.05$ as compared with ANIT group.

disorder (Korolenko et al., 2012). Intrahepatic cholestasis induced by alpha-naphthylisothiocyanate (ANIT) is a proper model for studies of compensatory mechanisms in spontaneous recovery of liver function. A limited number of therapeutic strategies of liver injury and disease, are currently available. Over the past few decades, researchers have focused on drug discovery from marine medicines, an important group of complementary and alternative medicine therapy. It has shown that the use of sea urchin shells confers certain beneficial advantages, including antioxidant and pharmaceutical effects (Shankarlal et al., 2011). The sea urchin, Paracentrotus lividus (Dincer and Cakli, 2007) is a keystone herbivore in the Mediterranean Sea (Ruocco et al., 2017). It has special substances, such as quinonoid pigments which called echinochromes (Mohamed et al., 2016).

Serum AST and ALT activities are usually used for the precise detection and early diagnosis of liver function. The present study confirmed the studies of Fahmy (2015), who showed that both AST and ALT activities increased in cholestatic rats. The elevations in ALT and AST may be associated with the escape of these enzymes from damaged hepatocytes. Moreover, Olteanu et al. (2012) explained the elevation in the AST and ALT to the increase in hepatic cell membrane fluidity that led to enzyme release into circulation. In agreement with the finding of Saleh et al. (2015), the treatment with all tested doses of Ech in the present study substantially attenuated the flares of the hepatic enzymes in cholestatic rats. It could be indicating maintenance of functional integrity of hepatic cell membrane. The recorded results confirmed by the recorded histopathological findings, which revealed that the treatment with Ech ameliorates the worsening effect of intrahepatic cholestasis induced by ANIT.

The liver is the major source of most serum proteins (Thapa and Walia, 2007). Improvement of total protein (TP) content can be suggested as a valuable directory of the severity of cellular dysfunction in liver diseases. The present study extended to confirm the finding of Sharma and Shukla (2011) that showed significant increase in serum TP content following cholestasis. The recorded increase in the TP may be due to endotoxemia, which frequently follows cholestasis as confirmed by Saleh et al. (2015) or contributory self-healing mechanism that accelerates liver regeneration process (Fahmy, 2015). The treatment with the tested doses of Ech in the present study relatively restores serum TP concentrations as compared to control group. In accord with our finding, Iwuanyanwu et al. (2011) attributing the restoring of the TP level following Ech treatment to its ability to retrieve naturalistic action.

Albumin is the most important protein in plasma synthesized by the liver and is a useful marker of hepatic function (Singh et al., 2013). The present study is in conjunction with Helal et al. (2012) who showed significant decrease in albumin content in cholestatic rats. The recorded reduction in albumin level may be due to the significant injury of hepatocytes affecting the synthetic function of the liver. In addition, hypoalbuminaemia could be related to hepatic dysfunction and decreased protein synthesis. On the other hand, the serum albumin concentration of rats treated with the investigated doses of Ech in the present study relatively increased significantly as compared to ANIT group, which may be related to the antioxidant properties of Ech that closely return the normal structure and function of hepatocytes. The present results are in agreement with the finding of Fahmy (2015) who indicated that the increase in serum albumin may be due to enhanced synthesis of proteins and albumin that accelerate the regeneration process which affording protection to the liver.

Alkaline phosphatase (ALP) is determined in the cells of the bile duct and is often employed to assess the reliability of the plasma membrane of the liver (Ou et al., 2016). The data recorded in the present study showed a significant increase of the serum ALP activity in cholestatic rats, which consonance with the findings of Lin et al. (2012). This increase may be attributable to the retention of bile salts that damaged the membrane and consequently leads to the passing of the ALP enzyme into circulation. In the current study, treatment with all tested doses of Ech caused decreases in serum ALP activity as compared to ANIT group which may be a sign of hepatoprotective action of Ech. Again, the lowering of enzyme activity denotes functional reliability of the hepatic cell membrane (Fahmy and Hamdi, 2011).

Testing the levels of serum bilirubin is one of the most sensitive methods employed in the diagnosis of hepatic diseases (Tahan et al., 2010). Firstly, the conjugated bilirubin and hydrophobic bile salts have the most toxic effect during cholestasis (Faubion et al., 1999). In conjunction with the report of Chen et al. (2016), our investigation showed that the increase in cholestasis biomarkers as total bilirubin, direct bilirubin, and indirect bilirubin may be due to the degeneration of hepatocytes and blockage of bile ducts caused by the action of ANIT. On the other hand, treatment with Ech causes a general decrease in total bilirubin, direct bilirubin, and indirect bilirubin throughout, as compared to ANIT group. The recorded reductions may reflect the role of Ech in helping bilirubin clearance from circulation 
as recorded by $\mathrm{Ou}$ et al. (2016). Histopathological examination of liver sections confirmed our biochemical findings. Injection of ANIT induced a variety of hepatic histological changes, including widening of the portal tract, hemorrhage and edema, proliferation of bile ducts surrounded by inflammatory cell infiltration. These changes were significantly attenuated by Ech extract.

Oxidative stress $(\mathrm{OxS})$ that occurs during cholestasis plays a critical role in liver injury (Bessa et al., 2012). Oxidative stress is the result of an imbalance in pro-oxidant/antioxidant homeostasis (Rahman et al., 2012). Previous studies showed that mitochondria of hepatocytes generate reactive oxygen species (ROS) (Pastor et al., 1997). These mitochondrial free radicals production may be an important mechanism of cholestatic liver injury.

Malondialdehyde (MDA) is a secondary product of oxidative stress formed during lipid peroxidation after cholestasis (Somi et al., 2013). The stimulation of lipid peroxidation observed as a result of ANIT administration can be due to the formation of free radicals through an exhaustion of antioxidants leading to oxidative stress. The present study confirmed the studies of Ohta et al. (2006), who showed that the MDA levels increased significantly in cholestatic rats. The augmentation in MDA levels may be associated with hepatotoxicity and lipid peroxidation leading to tissue damage which confirmed in the present investigation by the histopathological results. However, in the present study, in agreement with the finding of Yeh et al. (2012) the treatment with Ech caused significant reduction in the level of MDA.

Glutathione reduced (GSH), a key antioxidant, is an important constituent of intracellular protective mechanisms against various noxious stimuli including oxidative stress (bener et al., 2005). The present study agreed the studies of Wang et al. (2014), who reported that a significant decrease in hepatic GSH content in cholestatic rats may be due to the secretion of a reversible glutathione-ANIT conjugate into bile which protects rats against ANIT-induced cholestasis. Our results also support the notion that depletion of tissue GSH as observed in ANIT induced hepatic injury is one of the major factors that permit lipid peroxidation and subsequent tissue damage. Treatment with all tested doses of Ech in the present study showed a significant increase in GSH content which may be an indication of the Ech ability to increase the synthesis of GSH in the liver through its antioxidant action as in accord with Wang et al. (2014).

The glutathione S-transferases (GST) are a family of enzymes that catalyze the conjugation of GSH with a variety of both xenobiotic and endobiotic compounds, which have electrophilic functional groups (Pickett and $\mathrm{Lu}, 1989)$. The present study is in conjunction with Saleh et al. (2015) who disclosed that, hepatic GST activity significantly decreased in cholestatic rats. This decrease in GST activity may be due to depletion of its substrate GSH that participate in ANIT toxicity and \or down regulation of the GST genes. In conjugation with Fahmy (2015), the treatment with all tested dose of Ech in the present study caused a significant increase in liver GST activity of cholestatic rats. This increase may be related to antioxidant enhancement of Ech that helping in restoration of the antioxidant system of hepatocytes (Yeh et al., 2012).

Nitric oxide (NO) plays a critical role on hepatic metabolism whether liver is in normal condition or in injury by different agents (Jin et al., 2013). NO acts as an inhibitor or agonist of cell signaling events. In the liver, constitutively generated NO maintains the hepatic microcirculation and endothelial integrity and it is found that NO has bidirectional effects when hepatic pathophysiological changes occur (Chen et al., 2003). The present study is in consonance with the findings of Zhao et al. (2013), who showed significant increase in NO activity in cholestatic rats, which indicated that hepatic damage may be caused by excessive NO production. NO proposed to play a role as a proinflammatory mediator to kill damaged hepatocytes, as viewed in conjunction with the finding of Liu and Waalkes, (2005). In present study the treatment with all tested doses of Ech showed decrease in NO activity. Ech could be play as anti-oxidative and anti-inflammatory agent as it is rich in flavonoids. This explanation is in accord with Yan et al. (2015) who reported that decrease the release of $\mathrm{NO}$ due to the effect of total flavonoids present in the plant extract.

In conclusion, the present study revealed that Ech had positive antioxidant effect against ANIT -induced cholestasis in rats as it alleviates the alterations in oxidative stress, improved antioxidant status through activation of free radical scavenging enzymes, thereby it could be recommended as a good new therapeutic for cholestasis in humans. The results confirmed by the histopathological finding which revealed that the treatment with Ech ameliorates the worsening effect of intrahepatic cholestasis induced by ANIT, suggesting that treatment with Ech may be a potential and effective new strategy for the prevention of hepatic failure.

\section{Ethical consideration}

Experimental protocols and procedures used in this study were approved by the Cairo University, Faculty of Science Institutional Animal Care and Use Committee (IACUC) (Egypt), (CUFS/S/11/15).

\section{Acknowledgements}

The authors thank Dr. Ayman S Mohamed Lecturer at Zoology Department, Faculty of Science, Cairo University for his support.

\section{References}

BAAK, J.P.A. and OORT, J., 1983. Application of morphometry in tumour pathology. In: J.P.A. BAAK and J. OORT, ed. A manual of morphometry in diagnostic pathology. Berlin Heidelberg New York: Springer. http://dx.doi.org/10.1007/978-3-642-74823-3_7. 
BANCROFT, J.D. and GAMBLE, M. 2007. Theory and Practice of Histological Techniques. 5th ed. United Kingdom; Churchill Livingstone London, pp. 125-138.

BELFIELD, A. and GOLDBERG, D.M., 1971. Revised assay for serum phenyl phosphatase activity using 4-aminoantipyrine. Enzyme, vol. 12, no. 5, pp. 561-573. http://dx.doi. org/10.1159/000459586. PMid:5169852.

BESSA, S.S., MOHAMED ALI, E.M., ABD EL-WAHAB, A.-S. and NOR EL-DIN, S.A., 2012. Heme oxygenase-1 mRNA expression in Egyptian patients with chronic liver disease. Hepatitis Monthly, vol. 12, no. 4, pp. 278-285. http://dx.doi.org/10.5812/ hepatmon.846. PMid:22690236.

BEUTLER, E., DURON, O. and KELLY, M.B., 1963. Improved method for the determination of blood glutathione. The Journal of Laboratory and Clinical Medicine, vol. 61, pp. 882-888. PMid:13967893.

CHEN, H., HUANG, X., MIN, J., LI, W., ZHANG, R., ZHAO, W., LIU, C., YI, L., MI, S., WANG, N., WANG, Q. and ZHU, C., 2016. Geniposidic acid protected against ANIT-induced hepato toxity and acute intrahepatic cholestasis, due to Fxr-mediate dregulation of Bsep and Mrp2. Journal of Ethnopharmacology, vol. 179, pp. 197-207. http://dx.doi.org/10.1016/j.jep.2015.12.033. PMid:26723467.

CHEN, T., ZAMORA, R., ZUCKERBRAUN, B. and BILLIAR, T.R., 2003. Role of nitric oxide in liver injury. Current Molecular Medicine, vol. 3, no. 6, pp. 519-526. http://dx.doi. org/10.2174/1566524033479582. PMid:14527083.

CLARK, A.M. and ROWE, F.E.W., 1971. Monograph of shallow water Indo west pacific echinoderms. British Museum, vol. 690, pp. 1-238.

DATTA, D., TALAPATRA, S.N. and SWARNAKAR, S., 2015. Bioactive compounds from marine invertebrates for potential medicines - An overview. International Letters of Natural Science, vol. 34, pp. 42-61. http://dx.doi.org/10.18052/www. scipress.com/ILNS.34.42.

DINCER, T. and CAKLI, S., 2007. Chemical composition and biometrical measurements of the Turkish Sea urchin (Paracentrotus lividus, Lamarck, 1816). Critical Reviews in Food Science and Nutrition, vol. 47, no. 1, pp. 21-26. http://dx.doi. org/10.1080/10408390600550265. PMid:17373092.

EL-SISI, A., HEGAZY, S. and EL-KHATEEB, E., 2013. Effects of three different fibrates on intrahepatic cholestasis experimentally induced in rats. PPAR Research, vol. 781348, pp. 10. PMid:23997763.

FAHMY, S.R., 2015. Anti-fibrotic effect of Holothuria arenicola extract against bile duct ligation in rats. BMC Complementary and Alternative Medicine, vol. 15, no. 1, pp. 14. http://dx.doi. org/10.1186/s12906-015-0533-7. PMid:25652675.

FAHMY, S.R. and HAMDI, S.A., 2011. Curative effect of the Egyptian marine Erugosquilla massavensis extract on carbon tetrachloride-induced oxidative stress in rat liver and erythrocytes. European Review for Medical and Pharmacological Sciences, vol. 15, no. 3, pp. 303-312. PMid:21528777.

FAUBION, W.A., GUICCIARDI, M.E., MIYOSHI, H., BRONK, S.F., ROBERTS, P.J., SVINGEN, P.A., KAUFMANN, S.H. and GORES, G.J., 1999. Toxic bile salts induce rodent hepatocyte apoptosis via direct activation of Fas. The Journal of Clinical Investigation, vol. 103, no. 1, pp. 137-145. http://dx.doi. org/10.1172/JCI4765. PMid:9884343.
HABIG, W.H., PABST, M.J. and JAKOBY, W.B., 1974. Glutathione S-transferases. The first enzymatic step in mercapturic acid formation. The Journal of Biological Chemistry, vol. 249, no. 22, pp. 7130-7139. PMid:4436300.

HAN, J.M., KIM, H.G., CHOI, M.K., LEE, J.S., PARK, H.J., WANG, J.H., LEE, J.S., SON, S.W., HWANG, S.Y. and SON, C.G., 2012. Aqueous extract of Artemisia iwayomogi Kitamura attenuates cholestatic liver fibrosis in a rat model of bile duct ligation. Food and Chemical Toxicology, vol. 50, no. 10, pp. 35053513. http://dx.doi.org/10.1016/j.fct.2012.07.018. PMid:22824087.

HELAL, E.G., EL-WAHAB, S.M.A. and SHARAF, A.M.M., 2012. Effect of Zingiber officinale on fatty liver induced by oxytetracycline in albino rats. The Egyptian Journal of Hospital Medicine, vol. 46, pp. 26-42.

HO, Y.J., LEE, A.S., CHEN, W.P., CHANG, W.L., TSAI, Y.K., CHIU, H.L., KUO, Y.H. and SU, M.J., 2014. Caffeic acid phenethyl amide ameliorates ischemia/reperfusion injury and cardiac dysfunction in streptozotocin-induced diabetic rats. Cardiovascular Diabetology, vol. 13, no. 1, pp. 98. http://dx.doi. org/10.1186/1475-2840-13-98. PMid:24923878.

IWUANYANWU, P.K., ONYEMAENU, C. and WEGWU, M., 2011. Hepatotoxic and nephrotoxic effects of kerosene and petrol-contaminated diets in Wistar albino rats. Research Journal of Environmental Toxicology, vol. 5, no. 1, pp. 49-57. http://dx.doi. org/10.3923/rjet.2011.49.57.

JIN., F., CHENG, D., TAO, J.Y., ZHANG, S.L., PANG, R., GUO, Y.J., YE, P., DONG, J.H., ZHAO, L. 2013 Anti-inflammatory and antioxidative effects of corilagin in a rat model of acute cholestasis. BMC Gastroenterolgy, vol. 13, pp. 79.

JÜNGST, C., BERG, T., CHENG, J., GREEN, R.M., JIA, J., MASON, A.L. and LAMMERT, F., 2013. Intrahepatic cholestasis in common chronic liver diseases. European Journal of Clinical Investigation, vol. 43, no. 10, pp. 1069-1083. http://dx.doi. org/10.1111/eci.12128. PMid:23927644.

KOROLENKO, T.A., LEVINA, O.A., FILJUSHINA, E.E. and SAVCHENKO, N.G. 2012. Drug-Induced Models of Cholestasis and Lysosomes. In: V. TRIPODI, ed. Cholestasis. London: InTech, $98 \mathrm{p}$.

KRELL, H., HOKE, H. and PFAFF, E., 1982. Development of intra-hepatic cholestasis by alpha-naphthylisothiocyanate in rats. Gastroenterology, vol. 82, no. 3, pp. 507-514. PMid:7054045.

KUWAHARA, R., HATATE, H., YUKI, T., MURATA, H., TANAKA, R. and HAMA, Y., 2009. Antioxidant property of polyhydroxylated naphthoquinone pigments from shells of purple sea urchin Anthocidariscrassi spina. Lebensmittel-Wissenschaft + Technologie, vol. 42, no. 7, pp. 1296-1300. http://dx.doi. org/10.1016/j.lwt.2009.02.020.

LENG, Y.P., QIU, N., FANG, W.J., ZHANG, M., HE, Z.M. and XIONG, Y., 2014. Involvement of increased endogenous asymmetric dimethylarginine in the hepatic endoplasmic reticulum stress of type 2 diabetic rats. PLoS One, vol. 9, no. 2, pp. 97125. http://dx.doi.org/10.1371/journal.pone.0097125. PMid:24918756.

LENNIKOV, A., KITAICHI, N., NODA, K., MIZUUCHI, K., ANDO, R., DONG, Z., FUKUHARA, J., KINOSHITA, S., NAMBA, K., OHNO, S. and ISHIDA, S., 2014. Amelioration of endotoxin-induced uveitis treated with the sea urchin pigment echinochrome in rats. Molecular Vision, vol. 20, pp. 171-177. PMid:24520186. 
LEVINSKY, W.J., SMALLEY, R.V., HILLYER, P.N. and SHINDLER, R.L., 1970. Arsine hemolysis. Archives of Environmental Health, vol. 20, no. 3, pp. 436-440. http://dx.doi. org/10.1080/00039896.1970.10665616. PMid:5415845.

LIN, T.K., HUANG, L.T., HUANG, Y.H., TIAO, M.M., TANG, K.S. and LIOU, C.W., 2012. The effect of the red wine polyphenol resveratrol on a rat model of biliary obstructed cholestasis: involvement of anti-apoptotic signalling, mitochondrial biogenesis and the induction of autophagy. Apoptosis, vol. 17, no. 8, pp. 871-879. http://dx.doi.org/10.1007/s10495-012-0732-3. PMid:22562605.

LIU, J. and WAALKES, M.P., 2005. Nitric oxide and chemically induced hepatotoxicity: beneficial effects of the liver-selective nitric oxide donor, V-PYRRO/NO. Toxicology, vol. 208, no. 2, pp. 289-297. http://dx.doi.org/10.1016/j.tox.2004.11.017. PMid:15691592.

LIU, R., CHEN, H., BAI, H., ZHANG, W., WANG, X., QIN, X., ZHANG, X., LI, W., LIANG, X. and HAI, C., 2013. Suppression of nuclear factor erythroid 2-related factor 2 via extracellular signalregulated kinase contributes to bleomycin-induced oxidative stress and fibrogenesis. Toxicology Letters, vol. 220, no. 1, pp. 15-25. http://dx.doi.org/10.1016/j.toxlet.2013.03.034. PMid:23570914.

MOHAMED, A.S., SOLIMAN, A.M. and MARIE, M.A.S., 2016. Mechanisms of Echinochrome potency in modulating diabetic complication in liver. Life Sciences, vol. 151, pp. 41-49. http://dx.doi.org/10.1016/j.1fs.2016.03.007. PMid:26947587.

MONTGOMERY, H.A.C. and DYMOCK, J.F., 1961. The determination of nitrite in water. Analyst, vol. 86, pp. 414-416.

OHKAWA, H., OHISHI, N. and YAGI, K., 1979. Assay for lipid peroxides in animal tissues by thiobarbituric acid reaction. Analytical Biochemistry, vol. 95, no. 2, pp. 351-358. http://dx.doi. org/10.1016/0003-2697(79)90738-3. PMid:36810.

OHTA, Y., KONGO-NISHIMURA, M., IMAI, Y., MATSURA, T., KITAGAWA, A. and YAMADA, K., 2006. $\alpha$-Tocopherol protects against $\alpha$-naphthylisothiocyanate-induced hepatotoxicity in rats less effectively than melatonin. Chemico-Biological Interactions, vol. 161, no. 2, pp. 115-124. http://dx.doi.org/10.1016/j. cbi.2006.03.006. PMid:16626673.

OLTEANU, D., FILIP, A., MUREŞAN, A., NAGY, A., TABARAN, F., MOLDOVAN, R., DECEA, N., CATOI, C. and CLICHICI, S., 2012. The effects of chitosan and low dose dexamethasone on extrahepatic cholestasis after bile duct ligation in Wistar rats. Acta Physiologica Hungarica, vol. 99, no. 1, pp. 61-73. http://dx.doi. org/10.1556/APhysiol.99.2012.1.7. PMid:22425809.

OU, Q.Q., QIAN, X.H., LI, D.Y., ZHANG, Y.X., PEI, X.N., CHEN, J.W. and YU, L., 2016. Yinzhihuang attenuates ANITinduced intrahepatic cholestasis in rats through upregulation of Mrp2 and Bsep expressions. Pediatric Research, vol. 79, no. 4, pp. 589-595. http://dx.doi.org/10.1038/pr.2015.252. PMid:26646631.

PANDIT, R., ANNAMMA, A., ARVIND, L. and MADHAVI I. 2009. Evaluation of antiangiogenic activity through tubulin interaction of chloroform fraction of the feather star, Lamprometra palmata palmate. Indian Journal of Geo-Marine Science, vol. 38 , no. 1 , pp. $28-37$.

PASTOR, A., COLLADO, P.S., ALMAR, M. and GONZALEZGALLEGO, J., 1997. Antioxidant enzyme status in biliary obstructed rats: effects of N-acetylcysteine. Journal of Hepatology, vol. 27 , no. 2, pp. 363-370. http://dx.doi.org/10.1016/S01688278(97)80183-3. PMid:9288612.
PICKETT, C.B. and LU, A.Y.H., 1989. Glutathione S- transferases: Gene structure, regulation and biological function. Annual Review of Biochemistry, vol. 58, no. 1, pp. 743-764. http://dx.doi.org/10.1146/ annurev.bi.58.070189.003523. PMid:2673020.

RAHMAN, T., HOSEN, I., TOWHIDUL ISLAM, M.M. and SHEKHAR, H.U., 2012. Oxidative stress and human health. Advances in Bioscience and Biotechnology, vol. 3, no. 07, pp. 997-1019. http://dx.doi.org/10.4236/abb.2012.327123.

REITMAN, S. and FRANKEL, S., 1957. A colorimetric method for the determination of serum glutamic oxaloacetic and glutamic pyruvic transaminases. American Journal of Clinical Pathology, vol. 28, no. 1, pp. 56-63. http://dx.doi.org/10.1093/ajcp/28.1.56. PMid:13458125.

RIGUERA, R., 1997. Isolating bioactive compounds from marine organisms. Journal of Marine Biotechnology, vol. 5, pp. 187-193.

RODRÍGUEZ-GARAY, E.A., 2003. Cholestasis: human disease and experimental animal models. Annals of Hepatology, vol. 2, no. 4, pp. 150-158. PMid:15115953.

RUOCCO, N., COSTANTINI, S., ZUPO, V., ROMANO, G., IANORA, A., FONTANA, A. and COSTANTINI, M., 2017. High-quality RNA extraction from the sea urchin Paracentrotus lividus embryos. PLoS One, vol. 12, no. 2, pp. e0172171. http:// dx.doi.org/10.1371/journal.pone.0172171. PMid:28199408.

SALEH, H., SOLIMAN, A.M., MOHAMED, A.S. and MARIE, M.A.S., 2015. Antioxidant effect of sepia ink extract on extrahepatic cholestasis induced by bile duct ligation in rats. Biomedical and Environmental Sciences, vol. 28, no. 8, pp. 582594. PMid:26383596.

PENER, G., KABASAKAL, L., YÜKSEL, M., GEDIK, N. and ALICAN, Ý., 2005. Hepatic fibrosis in biliary-obstructed rats is prevented by Ginkgo biloba treatment. World Journal of Gastroenterology, vol. 11, no. 35, pp. 5444-5449. http://dx.doi. org/10.3748/wjg.v11.i35.5444. PMid:16222734.

SHANKARLAL, S., PRABU, K. and NATARAJAN, E., 2011. Antimicrobial and antioxidant activity of purple sea urchcin shell. American-Eurasian Journal of Scientific Research, vol. 6, no. 3, pp. 178-181.

SHARMA, N. and SHUKLA, S., 2011. Hepatoprotective potential of aqueous extract of Butea monosperma against $\mathrm{CCl}_{4}$ induced damage in rats. Experimental and Toxicologic Pathology, vol. 63, no. 7-8, pp. 671-676. http://dx.doi.org/10.1016/j.etp.2010.05.009. PMid:20561774.

SINGH, P., KHAN, S. and MITTAL, R.K., 2013. Prevalence of jaundice based on liver function test in Western Nepal. Bali Medical Journal, vol. 2, no. 2, pp. 72-74.

SOKOLOVIC, D., NIKOLIC, J., KOCIC, G., JEVTOVICSTOIMENOV, T., VELJKOVIC, A., STOJANOVIC, M., STANOJKOVIC, Z., SOKOLOVIC, D.M. and JELIC, M., 2013. The effect of UDCAdeoxycholic acid on oxidative stress level and DNase activity in rat liver after bile duct ligation. Drug and Chemical Toxicology, vol. 36, no. 2, pp. 141-148. http:// dx.doi.org/10.3109/01480545.2012.658919. PMid:22385135.

SOMI, M.H., KALAGEYCHI, H., HAJIPOUR, B., MUSAVI, G., KHODADADI, A., SHOKRI, N., HASHEMI, R., BAGHERI, I. and MUTAB LALEH, F., 2013. Lipoic acid prevents hepatic and intestinal damage induced by obstruction of the common bile duct in rats. European Review for Medical and Pharmacological Sciences, vol. 17, no. 10, pp. 1305-1310. PMid:23740441. 
SVEGLIATI BARONI, G., D'AMBROSIO, L., FERRETTI, G., CASINI, A., DI SARIO, A., SALZANO, R., RIDOLFI, F., SACCOMANNO, S., JEZEQUEL, A.M. and BENEDETTI, A., 1998. Fibrogenic effect of oxidative stress on rat hepatic stellate cells. Hepatology, vol. 27, no. 3, pp. 720-726. http://dx.doi. org/10.1002/hep.510270313. PMid:9500700.

SWARNALATHA, L. and REDDY, P.N., 2012. Hepatoprotective activity of Sphaeranthus amaranthoides on D-galactosamine induced hepatitis in albino rats. Asian Pacific Journal of Tropical Biomedicine, vol. 2, no. 3, pp. S1900-S1905. http://dx.doi. org/10.1016/S2221-1691(12)60518-8.

TAHAN, G., AKIN, H., AYDOGAN, F., RAMADAN, S.S., YAPICIER, O., TARCIN, O., UZUN, H., TAHAN, V. and ZENGIN, K., 2010. Melatonin ameliorates liver fibrosis induced by bile-duct ligation in rats. Canadian Journal of Surgery, vol. 53, no. 5, pp. 313-318. PMid:20858375.

THAPA, B.R. and WALIA, A., 2007. Liver function tests and their interpretation. Indian Journal of Pediatrics, vol. 74, no. 7, pp. 663-671. http://dx.doi.org/10.1007/s12098-007-0118-7. PMid:17699976.

TIETZ, N.W. 1990. Clinical guide to laboratory tests. 2nd ed. Philadelphia: WB Saunders; p. 566.

TIETZ, N.W. 1994. Fundamentals of clinical chemistry: 2nd ed. NW Tietz: Saunders; p 692.

WANG, T., ZHOU, Z., SUN, L., LI, X., XU, Z., CHEN, M., ZHAO, G., JIANG, Z. and ZHANG, L., 2014. Resveratrol effectively attenuates $\alpha$-naphthylisothiocyanate-induced acute cholestasis and liver injury through choleretic and anti-inflammatory mechanisms. Acta Pharmacologica Sinica, vol. 35, no. 12, pp. 1527-1536. http://dx.doi.org/10.1038/aps.2014.119. PMid:25418378.

XU, J., LEE, G., WANG, H., VIERLING, J.M. and MAHER, J.J., 2004. Limited role for CXC chemokines in the pathogenesis of alpha-naphthylisothiocyanate-induced liver injury. American Journal of Physiology. Gastrointestinal and Liver Physiology, vol. 287, no. 3, pp. G734-G741. http://dx.doi.org/10.1152/ ajpgi.00300.2003. PMid:15130876.

YAN, J.Y., AI, G., ZHANG, X.J., XU, H.J. and HUANG, Z.M., 2015. Investigations of the total flavonoids extracted from flowers of Abel-moschus manihot (L.) Medic against $\alpha$-naphthylisothiocyanate-induced cholestatic liver injury in rats. Journal of Ethnopharmacology, vol. 172, pp. 202-213. http:// dx.doi.org/10.1016/j.jep.2015.06.044. PMid:26133062.

YAN, J., XIE, G., LIANG, C., HU, Y., ZHAO, A., HUANG, F., HU, P., LIU, P., JIA, W. and WANG, X., 2017. Herbal medicine Yinchenhaotang protects against $\alpha$-naphthylisothiocyanate-induced cholestasis in rats. Scientific Reports, vol. 7, no. 1, pp. 4211. http://dx.doi.org/10.1038/s41598-017-04536-5. PMid:28646179.

YEH, Y.H., HSIEH, Y.L., LEE, Y.T. and HU, C.C., 2012. Protective effects of Geloina eros extract against carbon tetrachloride-induced hepatotoxicity in rats. Food Research International, vol. 48, no. 2, pp. 551-558. http://dx.doi.org/10.1016/j.foodres.2012.04.022.

ZHAO, Y., ZHOU, G., WANG, J., JIA, L., ZHANG, P., LI, R., SHAN, L., LIU, B., SONG, X., LIU, S. and XIAO, X., 2013. Paeoniflorin protects against ANIT-induced cholestasis by ameliorating oxidative stress in rats. Food and Chemical Toxicology, vol. 58, pp. 242-248. http://dx.doi.org/10.1016/j. fct.2013.04.030. PMid:23623840. 